\title{
DISTRIBUTION AND SIZE OF THE MOJARRA Diapterus rhombeus (CUVIER) (ACTINOPTERYGII, GERREIDAE) IN A SOUTHEASTERN BRAZILIAN BAY
}

\author{
Marcus Rodrigues da Costa ${ }^{1}$, Rafael Jardim Albieri ${ }^{2}$, Leonardo Mitrano Neves ${ }^{2}$, \\ Alex Braz Lacone Santos ${ }^{2}$ and Francisco Gerson Araujo ${ }^{2}$ \\ ${ }^{1}$ Módulo Centro universitário \\ (Avenida Frei Pacífico Wagner 653, 11660-903 Caraguatatuba, SP, Brasil)
}

${ }^{2}$ Universidade Federal Rural do Rio de Janeiro, Laboratório de Ecologia de Peixes (km 47 Antiga Rodovia Rio-SP, 23851-970, Seropédica, RJ, Brasil)

*Corresponding author: profmar@gmail.com

\section{A B S T R A C T}

Diapterus rhombeus is one of the most abundant fish species in the Sepetiba bay, which is a $520 \mathrm{~km}^{2}$ semi-closed coastal area in Southeastern Brazil. The size and distribution of this species have been described in order to assess the use of the area as a rearing ground in both spatial and temporal (seasonal) dimensions. A fish sampling program was conducted monthly by using an otter trawl between October 1998 and September 1999, in three bay zones (outer, middle and inner), defined according to depth and salinity gradient. Highly significant differences were found for CPUEs (number and biomass) among seasons and zones. Size ranged from 50 to $230 \mathrm{~mm} \mathrm{TL}$, and three sizegroups were defined according to a maturation scale $(\mathrm{n}=1435): 1$ - immature $(<80 \mathrm{~mm}$ Total Length - TL); 2- individuals at the first maturation (L50) $(80-90 \mathrm{~mm} \mathrm{TL}$ ), and 3 - adults (L100) (> $100 \mathrm{~mm}$ $\mathrm{TL}$ ). Immature and L50 individuals were more abundant (number and biomass) during Autumn in the inner zone, while adults (L100) predominated during Summer in the outer zone. Evidences of movements of young-of-the-year (50-90 mm TL) individuals from the inner to the outer zone were detected as they reach larger sizes $(180 \mathrm{~mm}$ TL) in the second year of life. Condition (k) was higher in larger sized individuals in the outer zone during Spring, when they are apt to start the reproductive process. Two cohorts were detected according to modal progression: the first (smaller size) showing faster growth than the second, evidencing a slower growth rate as they reach larger size. Distinct size classes occupying different bay zones suggest that the age-groups optimize their coexistence by partitioning the available resources, avoiding intra-specific competition.

\section{R E S U M O}

Diapterus rhombeus é uma das espécies de peixes mais abundantes na Baia de Sepetiba, ambiente costeiro de $520 \mathrm{~km}^{2}$ de área semifechada no sudoeste do Brasil. O tamanho e distribuição dos indivíduos desta espécie foram descritos com o objetivo de determinar o uso das áreas de criação numa dimensão espacial e temporal (sazonal). Um programa de amostragem de arrasto de fundo foi conduzido mensalmente entre outubro 1998 a setembro 1999, em três zonas da baía (externa, central, interna), definidas através de gradientes de profundidade e salinidade. Diferenças altamente significativas foram encontradas para CPUEs (número e biomassa) entre estações do ano e zonas. $\mathrm{O}$ comprimento variou de 50 a $230 \mathrm{~mm}$ CT. Três grupos de tamanhos foram definidos de acordo com uma escala de maturação gonadal $(\mathrm{n}=1435): 1$ - imaturo $(<80 \mathrm{~mm}$ Comprimento Total $-\mathrm{CT})$; 2indivíduos em primeira maturação (L50) (80-90 mm CT); e 3 - adultos (L100) (> $100 \mathrm{~mm}$ CT). Imaturos e indivíduos L50 foram abundantes (número e biomassa) durante o outono na zona interna, enquanto adultos (L100) predominaram durante o verão na zona externa. Evidências de movimento de indivíduos jovens (50-90 mm CT) da zona interna para zona externa foram detectadas conforme os animais foram atingindo maiores tamanhos ( $180 \mathrm{~mm} \mathrm{CT})$, no segundo ano de vida. A condição $(\mathrm{k})$ aumentou em indivíduos maiores na zona externa durante a primavera, quando estes se tornam aptos a iniciar o processo reprodutivo. Duas coortes foram detectadas de acordo com a progressão modal: a primeira (menores tamanhos) mostrando crescimento mais rápido do que a segunda, evidenciando uma taxa menor de crescimento a medida que atingem maiores tamanhos. Diferentes classes de comprimento ocupando diferentes zonas da baía sugerem que grupos de idades otimizam sua coexistência compartilhando os recursos disponíveis e evitando competição intra-especifica.

Descriptors: Growth, Coastal fishes, Life cycle, Sepetiba Bay.

Descritores: Crescimento, Peixes costeiros, Ciclo de vida, Baía de Sepetiba. 


\section{INTRODUCTION}

Bays are coastal areas used as rearing grounds by a large number of juveniles of marine fish species due to abundant feeding resources and lesser predation risks favored by shallow depths and turbid waters. Members of the Gerreidae family rank among those most abundant fishes in tropical bays, and are distributed along the Western Atlantic from the Caribbean $\left(20^{\circ} \mathrm{N}\right)$ to Southern Brazil $\left(30^{\circ} \mathrm{S}\right)$. There is little information on their life cycle, and what exists relates mainly to possible uses of bays as feeding areas and the nearby platform as spawning areas (Cyrus; Blaber, 1984; Thayer et al., 1987). Gerrids popularly known as mojarras are typically eurihaline species and take part in the trophic web as transferor of energy between the primary consumers and top piscivores since they prey on components of the benthic macrofauna (Livingston et al., 1976; Aguirre-León et al., 1982; Cervigón; Gómez, 1986; Santos; Araújo, 1997). There is some indication that Diapterus rhombeus spawns in deep areas whereas juveniles use shallow waters in estuaries, bays and mangroves, as part of their life cycle (Chaves; Otto, 1998). High primary productivity in bays provides favorable conditions for recruitment and rearing grounds for juveniles of several fish species. Diapterus rhombeus is one of the most common species in experimental bottom trawls in the Sepetiba bay, on the coast of
Southeastern Rio de Janeiro State (Lat. $23^{\circ} \mathrm{S}$ ). It ranks as the sixth most abundant species, accounting for $4.6 \%$ of the total number of fishes, being present in $50.7 \%$ of all samples (Araújo et al., 1998). Understanding the way in which this species successfully uses the bay in such high abundance and with such wide distribution is important for fisheries management.

It is largely accepted that species of wide geographical distribution tend to be high abundant locally (Hanski et al., 1993). In this study, we tested the hypothesis that D. rhombeus attains high abundance by shifting its occurrence in the bay seasonally, over its life cycle, aiming to optimize the use of the available resources and attains great abundance in the area. The focus of this study was to determine the pattern of usage of Sepetiba Bay by $D$. rhombeus, based on the size structure of the population.

\section{Study Area}

Sepetiba bay is located in southeastern Rio de Janeiro State (latitudes $22^{\circ} 54^{\prime}-23^{\circ} 04^{\prime} \mathrm{S}$; longitudes $43^{\circ} 34^{\prime}-44^{\circ} 10^{\prime} \mathrm{W}$ ) (Fig. 1). It has an area of ca. 520 $\mathrm{km} 2$ and receives fluvial sediment transported by rivers and from tidal creeks and mangrove swamps, presenting a trend of semi-confinement to closure (Barroso, 1989).

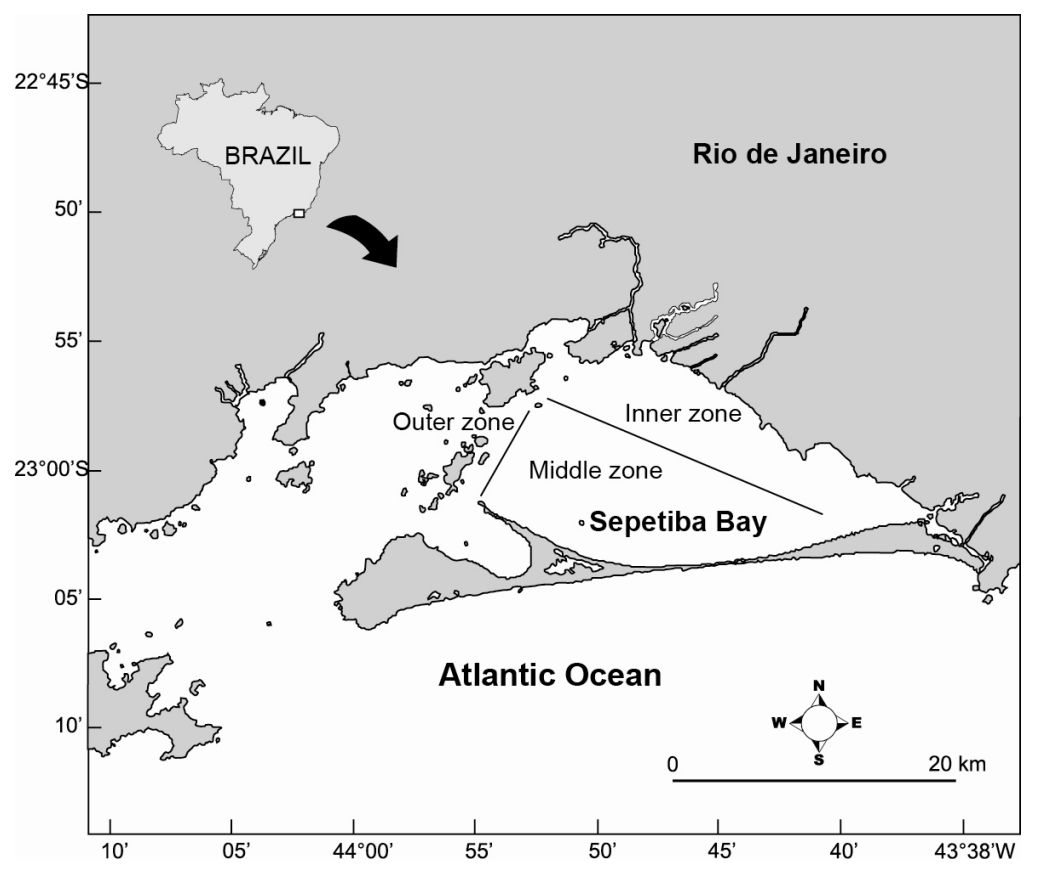

Fig. 1. Map showing the three zones (outer, middle and inner) of Sepetiba Bay, Brazil. 
The bay has distinct zones: an inner zone greatly affected by rivers and tidal creeks; an outer zone, closer to the sea limit, and a transitional (central) zone located between the former zones and presenting intermediate environmental characteristics. In the outer bay, the substratum is predominantly coarse and sandy, and rocky islands are common. In the inner bay the substratum is mostly muddy and the beaches are rocky, sandy and muddy, in places fringed by mangrove formations in that area. In spite of being up to $30 \mathrm{~m}$ deep near the sea limit, about $40 \%$ of the bay's area presents depths of less than $5 \mathrm{~m}$. Salinity ranges from 28.3 to 34 , and temperature varies from $21.5^{\circ} \mathrm{C}$ in winter to $27^{\circ} \mathrm{C}$ in summer (Araújo et al., 2002). Tide amplitude is $c a .1 \mathrm{~m}$, and southwestern and northeastern winds help, respectively, to bring seawater into the bay and out of it towards the continental shelf (Signorini, 1980). Three zones were designated in the bay according to depth and salinity gradient: 1) an inner zone, with a depth of less than $5 \mathrm{~m}$, located in the innermost bay area, affected by rivers and tidal creeks; 2) a middle zone, with depths of between 5 and $10 \mathrm{~m}$; and 3) an outer zone, with a depth of more than $10 \mathrm{~m}$, in the outmost bay area, subject to marine influence.

\section{Material And Methods}

Fish sampling was conducted monthly in each of the three bay zones, by using an otter trawl, between October 1998 and September 1999. Samplings were performed during the day on the bottom, for $20 \mathrm{~min}$. at 2 knots, thus covering approximately $1.5 \mathrm{Km}$. Tows were performed in triplicate and the catch per unit effort (CPUE) unit used for the study was the total number and weight of fish caught per tow.

All fish were fixed in $10 \%$ formalin and preserved in $70 \%$ alcohol. Fishes were measured to the nearest $\mathrm{mm}$ and weighed to the nearest $0.1 \mathrm{~g}$. Vouchers were deposited at fish collection of the Federal Rural University of Rio de Janeiro.

Relative abundance was assessed by CPUEs in numbers and weight. Size groups were defined according to the following maturity scale (Araújo et al., 1999): 1 - Immature individuals < $80 \mathrm{~mm}$ TL; 2 Individuals at first maturity $(\mathrm{L} 50)=80-90 \mathrm{~mm}$ TL; and 3 - adult individuals (L100) $>90 \mathrm{~mm}$ TL.

Two-way analysis of variance (ANOVA, P < 0.05 ) was used to compare relative abundance (CPUEs - number and weight) of size groups among zones and seasons followed by an a posteriori Tukey HSD test, with the rejection of the null hypothesis. All the raw data were $\log$-transformed $(\log 10(X+1))$ in the attempt to accomplish with ANOVA assumptions (Zar
1996). Seasons were assessed as follows: Spring (October, November and December); Summer (January, February and March); Autumn (April, May and June), and Winter (July, August and September). Length-weight relationship was determined by the power function $\mathrm{Wt}=\mathrm{a} * \mathrm{Lt} \mathrm{b}$ (Le Cren, 1951), where Wt is the total weight, Lt the total length, "a" the regression constant, related to the fish's condition, and "b" the regression coefficient, related to the form of the fish. The "a" and "b" values were estimated by ordinary least square (predictive model), after $\log 10$ transformation according to the following equation: $\log 10 \mathrm{Wt}=\log \mathrm{a}+\mathrm{b} * \log 10 \mathrm{Lt}$. The null hypothesis for isometry was tested for the regression coefficient using Student's $t$-test and the value was compared with the critical $t$ value. The condition factor (K) was calculated by the equation K = Wt/ Ltb (Santos, 1978). Size structure was assessed to estimated indirect growth by the monthly length frequency distributions, with individuals grouped in $5 \mathrm{~mm}$ size classes. Monthly frequency distributions were submitted to the ELEFAN I subroutine of the FISAT software Gayanilo-Jr and Pauly (1997), giving K (growth coefficient) and $Æ$ (performance index). The L $\infty$ parameter (asymptotic size) was determined by Taylor's (1962) equation ( $\mathrm{\infty} \infty=$ TL maximum / 0.95).

\section{RESULTS}

A total of 1435 individuals were caught, weighting 30,788.1 g. A subsample of 741 individuals was measured for Total Length (in $\mathrm{mm}$ ). Highly significant differences in CPUEs (number and weight) were found between seasons and zones for different phases of the life cycle (Table 1).

Adult fish (TL > $90 \mathrm{~mm}$; L100) were more abundant in Summer in the outer zone and in Autumn in the inner zone, while immature and individuals at first maturity (L50) were more abundant during the Autumn in the inner zone. Higher biomass (weight) characterized by large weight groups (Adults) occurred mainly in Summer and Autumn in the outer zone (Fig. 2).

Size structure ranged from 50 to $230 \mathrm{~mm}$ total length (TL), with mode of $90 \mathrm{~mm}$ in the inner zone, $145 \mathrm{~mm}$ in the middle zone and $190 \mathrm{~mm}$ TL in the outer zone (Fig. 3) suggesting size segregation along the bay zones (Fig. 3).

The smallest sized group (TL $<110 \mathrm{~mm}$ ) was recorded mainly in Autumn, being absent in Spring and poorly represented in Summer and Winter. Conversely, the largest sized individuals (TL > 160 $\mathrm{mm}$ ) occurred mainly in Summer and to a lesser extent in Autumn (Fig. 4). 
Table 1. F-values from two-way ANOVA and significant differences in CPUE - Number and Weight of Diapterus rhombeus in Sepetiba bay, RJ, Oct-1998 to Sep-1999. Seasons: S = spring, $\mathrm{Su}=$ summer, $\mathrm{A}=$ Autumn and $\mathrm{W}=$ Winter; Zones: $\mathrm{I}=$ inner, $\mathrm{M}=$ middle and $\mathrm{O}=$ outer. Number $=\mathrm{N}$ and Weight $=\mathrm{W} . *=\mathrm{p}<0.05 ; * *=\mathrm{p}<0.01 ; \mathrm{Ns}=$ not significant.

\begin{tabular}{|c|c|c|c|c|}
\hline Size Classes & Seasons (S) & Z Zones (Z) & Interaction $(\mathrm{S} \times \mathrm{Z})$ & Tukey test \\
\hline Immature - N & $3.90 *$ & $7.32 * *$ & $3.90 *$ & $\begin{array}{l}\text { Seasons: A > S, W } \\
\text { Zones: } \mathrm{I}>\mathrm{M}, \mathrm{O}\end{array}$ \\
\hline Immature - W & $6.22 * *$ & $12.91 * *$ & $6.22 * *$ & $\begin{array}{l}\text { Seasons: } \mathrm{A}>\mathrm{S}, \mathrm{W} \\
\text { Zones: } \mathrm{I}>\mathrm{M}, \mathrm{O}\end{array}$ \\
\hline $\mathrm{L} 50-\mathrm{N}$ & $5.69^{* *}$ & $12.79 * *$ & $5.69 * *$ & $\begin{array}{l}\text { Seasons: } \mathrm{A}>\mathrm{S}, \mathrm{Su}, \mathrm{W} \\
\text { Zones: } \mathrm{I}>\mathrm{M}, \mathrm{O}\end{array}$ \\
\hline $\mathrm{L} 50-\mathrm{W}$ & $6.14 * *$ & $16.58 * *$ & $6.14 * *$ & $\begin{array}{l}\text { Seasons: A > S, Su, W } \\
\text { Zones: } \mathrm{I}>\mathrm{M}, \mathrm{O}\end{array}$ \\
\hline L100 - N & $4.51 *$ & $4.98 *$ & Ns & $\begin{array}{l}\text { Seasons: } \mathrm{Su}, \mathrm{A}>\mathrm{S} \\
\text { Zones: } \mathrm{O}>\mathrm{M}, \mathrm{I}\end{array}$ \\
\hline $\mathrm{L} 100-\mathrm{W}$ & $4.43 *$ & Ns & $3.79 * *$ & Seasons: $\mathrm{Su}, \mathrm{A}>\mathrm{S}$ \\
\hline
\end{tabular}
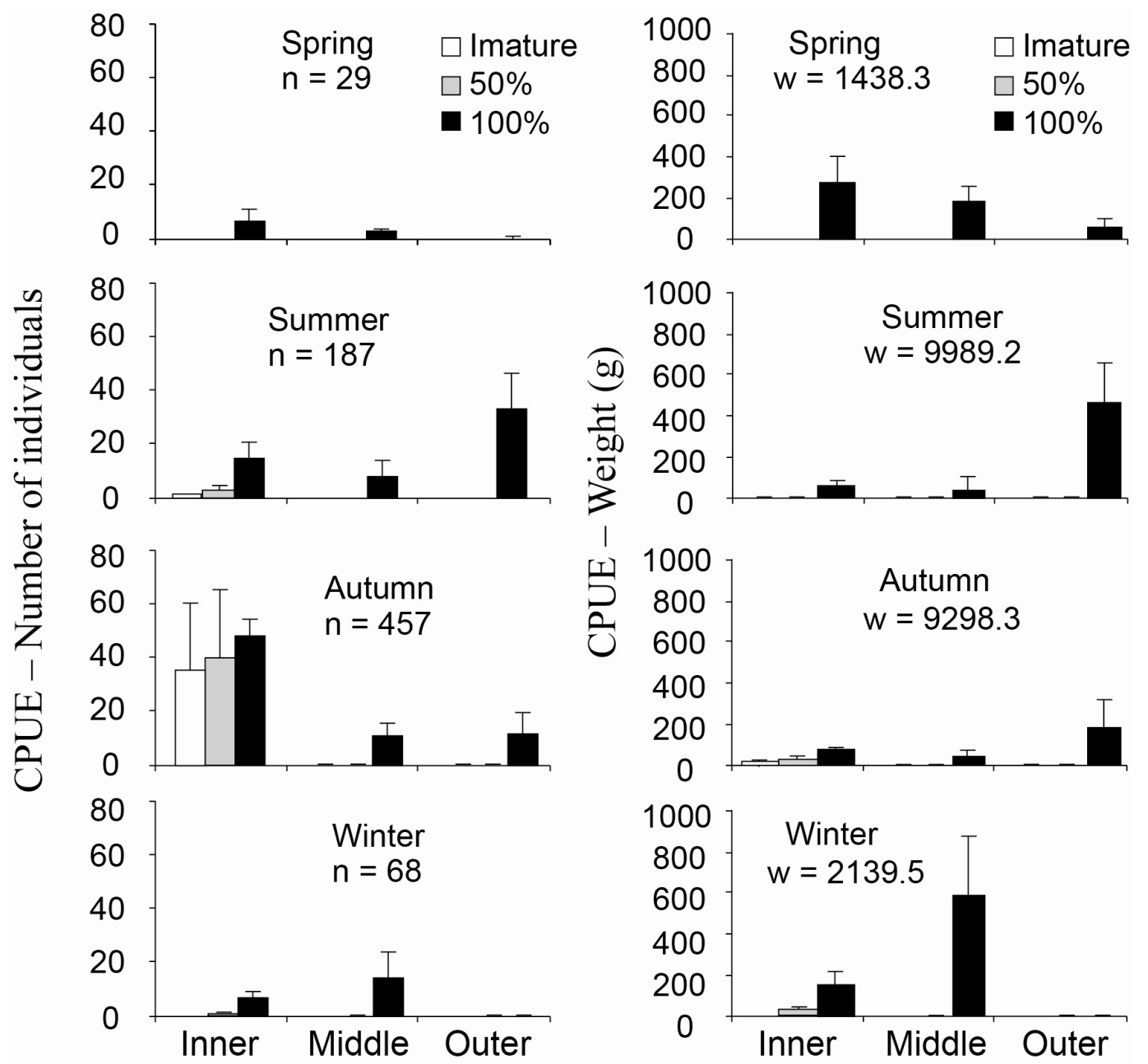

Fig. 2. Means and standard error (vertical bars) of CPUEs (number and weight-g) for D. rhombeus by zones and seasons in Sepetiba bay, RJ, Oct-1998 to Sep-1999. 


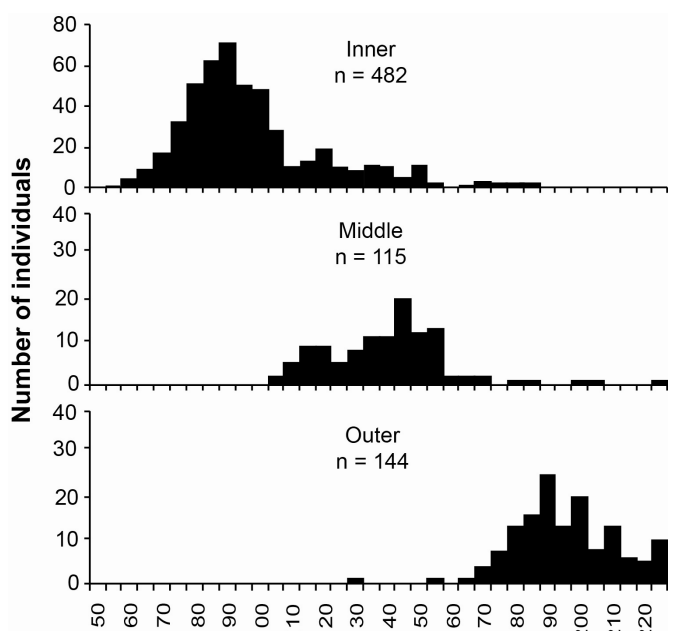

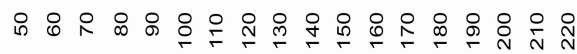
Total length $(\mathrm{mm})$
Fig. 4. Length frequency distribution for $D$. rhombeus by seasons in the Sepetiba bay, RJ, Oct-1998 to Sep1999.

Asymptotic length, determined by Taylor's formulae, was $358 \mathrm{~mm}$ TL, recorded in the outer zone. Estimation of the growth curve parameters, based on length-frequency distributions, considering nonoscillatory growth, were: $\mathrm{K}=0.57$ year $-1 \mathrm{Rn}=0.148$ and $Æ=4.86$ calculated by using the ELEFAN I subroutine, resulting in two cohorts for Sepetiba Bay's population (Fig. 5).
Fig. 3. Length-frequency distribution for $D$. rhombeus per zone in the Sepetiba bay, RJ, Oct-1998 to Sep-1999.

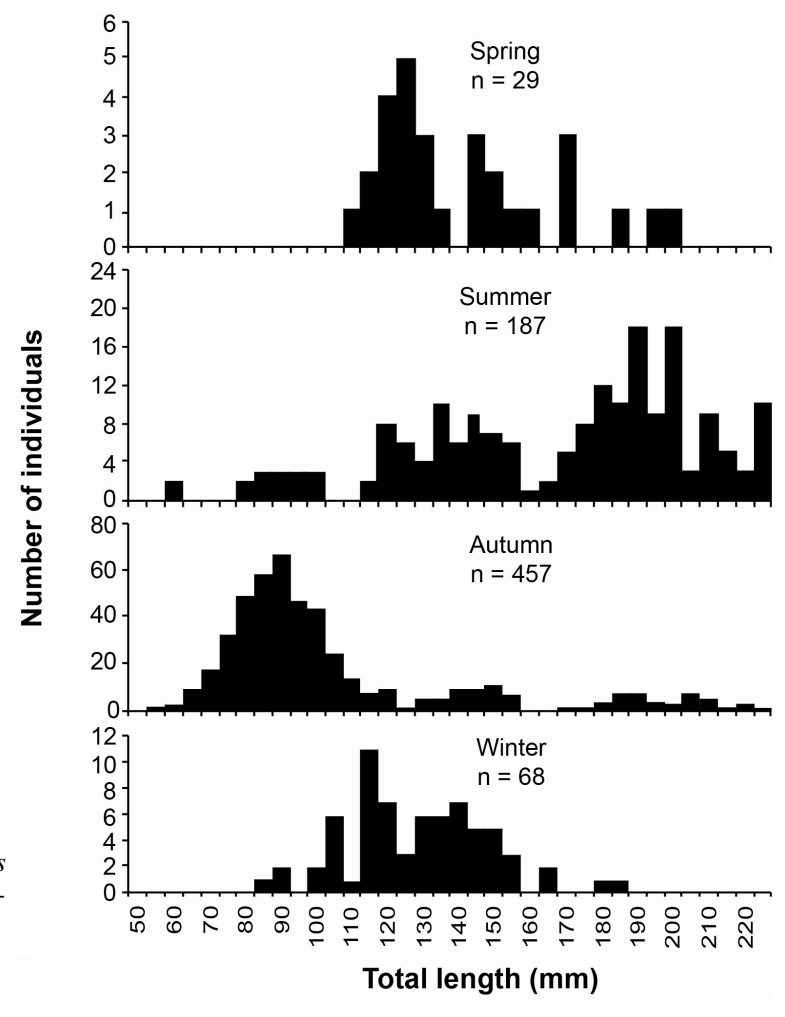

Early young-of-the-year (TL > $50 \mathrm{~mm}$ ) individuals appeared first in February and reached modal size of $90 \mathrm{~mm}$ TL in May, and $110 \mathrm{~mm}$ TL in August. Individuals showing $\mathrm{TL}=120 \mathrm{~mm}$ in October, are probably entering the second year, reaching $210 \mathrm{~mm}$ TL in June. Individuals during the first year showed faster growth than those in the second year, as a slower growth rate is to be expected as they reach larger sizes. 


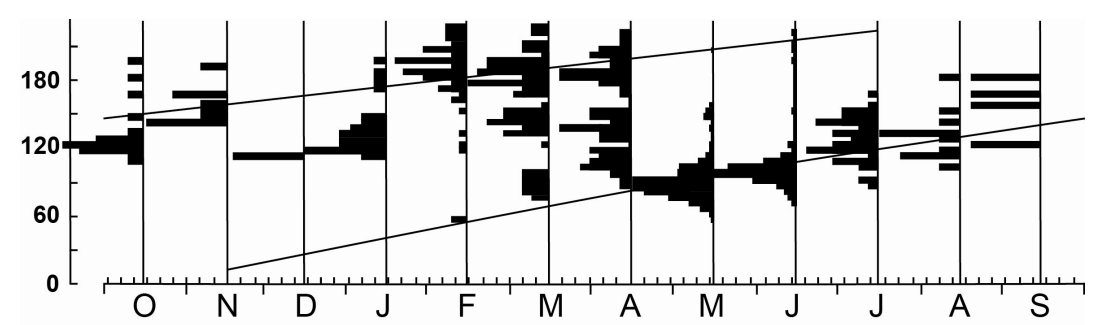

Fig. 5. Monthly modal progression with the respectives cohorts, obtained from ELEFAN I subroutine of FISAT software. Number of individuals: Oct-98 - 19, Nov = 8, Dec -2 , Jan-99 = 33, $\mathrm{Feb}=61, \mathrm{Mar}=93, \mathrm{Apr}=76$, May $=295, \mathrm{Jun}=86, \mathrm{Jul}=51, \mathrm{Aug}=13$ e Sep-99 $=4$.

The length-weight relationship was determined as the following power equation: $\mathrm{Wt}=$ $0.0051 \mathrm{Lt}^{3,3863}$ showing good adherence of the data to the model, according to the determination coefficient $(\mathrm{r} 2=0.972)$. The alometric coefficient (slope) departed significantly from 3 , according to the Student's $t$-test, indicating positive alometry, that is, the individuals tend to reach the maximum weight (asymptotic weight) at a relatively small size. This allometric coefficient also indicates that this species tends to present a relatively "hollow" form as it grows.

Condition factor showed slight seasonal variation, tending to higher values in Spring and Summer $(\mathrm{k}>0.0054)$ and lower values in Winter and Autumn $(\mathrm{k}<0.0053)$ although no significant difference was detected $(\mathrm{F}=0.21 ; \mathrm{p}=0.38)$. Spatially, the best condition was recorded for the outer bay zone $(\mathrm{k}>$ 0.0058), where the largest sized fishes predominate. A significantly lower condition ( $\mathrm{F}$ $=5.71 ; \mathrm{p}<0.01)$ was recorded for the central and inner Bay zones $(\mathrm{k}<0.0053)$, where there is a mixture of different size classes.

\section{Discussion}

Diapterus rhombeus is a species which has adapted well to Sepetiba bay by partitioning the use of the available resources among different size classes in space and time, avoiding intraspecific competition. This strategy is probably responsible for the success of this species which is abundant and widely distributed in the bay. Adults concentrate in the outer bay zone and possibly undertake little movement between the outer bay and the adjacent coastal shelf during Summer when the main reproductive events probably occur. Eggs and larvae are brought by currents to sandy beaches in the bay, where this species develop their early life phases during Summer and early Autumn.

Araújo and Santos (1999), using beach seines, found early recruits $(\mathrm{TL}=15-75 \mathrm{~mm}$ ) in large abundances off the sandy beaches in the inner bay between February and May, with this size group remaining in the shallow beach areas until the Autumn, when they moved to deeper bay areas. That movement pattern coincides with the findings of this study, which, differently from the beach seines used by the authors quoted, was based on otter trawls in deep areas of the bay, which recorded smaller-sized fishes (TL $>50 \mathrm{~mm}$ ) in the Autumn in the innermost bay zone, suggesting that this size group correspond to early recruits from the inner bay beaches. Afterwards, fishes larger than $50 \mathrm{~mm}$ TL are incorporated into the bottom trawls in the inner Bay zone. According to Ricklefs (2003), patterns of abundance and distribution of animal populations reflect the capacity of a given population to adjust to environmental constraints, in accordance with both the phenotypic and/or genotypic peculiarities of each species. Two main factors can explain the differences in abundance and distribution patterns of fish species between bays and coastal areas: 1) differences in environmental constraints, and 2) presence or absence of suitable microhabitats. It is hypothesized that the higher abundance of $D$. rhombeus in the inner bay zone was associated with the muddy substrate, where food availability is favoured by inputs of organic matter due to the presence of streams and mangrove creeks that drain effluents from the nearby urbanindustrial areas into the bay (Coelho; Carvalho, 1973; Pfeiffer, 1985). Organic loads trigger primary productivity in the bay, and they are not constraints or limiting factors for early $D$. rhombeus recruits. Juveniles can usually face such organic constraints better than adults which seem to be more sensitive to environmental changes (Martino and Able, 2003). Conversely, the larger-sized fishes, mainly adults, recorded in the more stable environmental condition of the outer bay zone, are evidence of such differentiated environmental selection by fish. Furthermore, there are strong evidences that fish which are ready to spawn (L100) move to outer bay zones, near to adjacent coastal areas where the spawning takes place in more stable and more favorable environmental conditions (Araújo et al. 1999). 
Shallow bay zones provide good recruitment and early growth conditions, being used as rearing grounds by several fish species, which take advantage of the suitable shelter and food availability. Feeding is favored by the input of organic matter, while protection against predation is favored by less transparent and shallower waters; these are the fundamental characteristics for the development of the fishes' early life cycle (Blaber; Blaber, 1980; Blaber et al., 1985; Peterson; Whitfield, 2000; Griffiths, 2001).

Diapterus rhombeus is considered a coastal marine fish species with greater dependence on semiclosed areas such as bays and estuaries. Juveniles and adults of this species are the main component of Sepetiba bay ichthyofauna, and only adults were recorded in the outer bay zone near to the adjacent coastal shelf as they reach larger size and are ready to spawn (Chaves; Otto, 1998; Araújo; Santos, 1999; Santos et al., 1997; Ayala-Perez et al., 2001). Larger (>160 mm TL) D. rhombeus individuals influxes to the outer bay zone occur in Summer, suggesting the movement of adults toward the adjacent coastal shelf. Fishes perform small-scale movements or large-scale migrations to explore other areas in order to maintain large population sizes (Weinstein et al., 1980; Wagner; Austin, 1999; Thiel; Potter, 2001). Gibson et al. (1998) reported three main reasons for seasonal fish migration, diel and tidal movements: (1) Feeding, (2) Protection from predation, and (3) Preference for favorable environmental conditions. Therefore, the highest abundance recorded in the inner bay zone and movements to the deeper bay zones reflect present and past environmental conditions to which these populations adapted and in which they developed. Hence, it is reasonable to hypothesize that $D$. rhombeus shows great ability to adjust to changing environmental conditions, moving along differentiated habitats according to the need to seek better conditions to feed, reproduce and take refuge.

Size structure in Sepetiba bay $(\mathrm{TL}=50-$ $230 \mathrm{~mm}$ ) was similar to those reported for other related systems. Chaves and Otto (1998) recorded a size range between 58 and $205 \mathrm{~mm}$ TL for Guaratuba bay $\left(26^{\circ} \mathrm{S}\right)$; Teixeira and Helmer (1997) found fish ranging from13-115 mm TL in the Mundaú/Manguaba coastal lagoon system (9oS). Etchevers (1978) recorded individuals ranging from 22 to $190 \mathrm{~mm} \mathrm{SL}$ in a Venezuelan coastal lagoon $(10 \mathrm{oN})$ and Ayala-Perez et al. (2001) reported a similar size range $(25-180 \mathrm{~mm}$ $\mathrm{TL})$ in the Términos lagoon $(19 \mathrm{oN})$, Mexico. Muto et al. (2000) reported individuals ranging from 153-235 $\mathrm{mm}$ TL on the São Sebastião coast $\left(24^{\circ} \mathrm{S}\right)$, an indication that smaller sizes are found in semi-closed areas such as bays and estuaries and only adults are distributed in adjacent coastal areas. Yánez-Arancibia and Sanches-Gil (1988) observed different size classes using different coastal habitats through seasonal movements as part of their life cycle, optimizing the use of the resources of the system. Although fishing effort and equipment were not similar at the different localities, different size groups indicate the species' adaptability as a characteristic strategy to enable it to exploit different habitats.

Two well define modal classes were observed in the present study; the first appearing with $60 \mathrm{~mm}$ TL in February, reaching approximately 130 $\mathrm{mm}$ TL in September. The second showing $140 \mathrm{~mm}$ TL in October and reaching $210 \mathrm{~mm}$ TL in June. Modal progression along seasons and bay zones indicates the movement of smaller-sized fishes in Summer/Autumn from the inner to the outer zone where larger individuals predominate, suggesting that they are apt to start the reproductive process, and that this coincides with the most favorable condition in the outer zone in Spring/Summer. Size at first maturity of $80 \mathrm{~mm}$ TL for both sexes was recorded for Sepetiba bay by Araújo and Santos (1999). Etchevers (1978) recorded a size of $132 \mathrm{~mm}$ SL for females and 126 $\mathrm{mm}$ SL for males at first maturation at Margarita Isle, Venezuela. Besides modal progression, indirect methods to estimate growth parameters used in this work confirmed the hypothesis that recruitment takes place mainly in Summer. The growth rate $(k)$ in the present study (0.57) was comparatively lower than those recorded for the Puerto Rico coastal area $(\mathrm{k}=0.66)$ by Austin (1971) and for Términos Lagoon, Mexico ( $r=0.74$ ) by Ayala-Perez et al. (2001). In the present study differences in growth rate between the two cohorts detected were observed, and they are probably due to the tactics and strategies developed by this species to ensure its survival in changing environmental conditions.

The best condition in the outer zone indicates that D. rhombeus is prepared to start the reproductive season. Large $\mathrm{k}$ parameter indicate greater fish weight for a given size (in length), coinciding with maturation and larger gonads, while lower values are associated with spent/spawned gonads (Vazzoler, 1996). Therefore, a subjective analysis of this parameter suggests that the spawning period is concentrated in Summer. Araújo et al. (1999) found a long spawning period for D. rhombeus in Sepetiba bay, ranging from Spring to Autumn. Chaves and Otto (1998) defined the Spring as the spawning season in the Guaratuba bay. Different spawning periods have been reported in Spring, Summer and Autumn at Margarita Isle, Venezuela (Etchevers, 1978) or Summer, Autumn and Winter in Puerto Rico (Austin, 1971), suggesting the wide reproductive plasticity of this species when exploiting different environmental conditions.

Both length-weight relationship and condition factor were calculated for both sexes pooled. 
Consequently, gonads of females may have influenced seasonal changes in individual weight more than males. Therefore, the highest condition factor $(\mathrm{K})$ is expected to occur just before the spawning period. The allometric coefficient in this study (3.4) was comparatively higher than those reported for other coastal areas such as the São Sebastião coastal shelf, SP (3.02) reported by Muto et al. (2000), the Margarita Isle (3.16) reported by (Etchevers, 1978) and Términos lagoon (3.15) reported by Ayala-Perez et al. (2001). On the other hand, the allometric coefficient for Sepetiba bay was similar to that recorded for Guarubuta bay (3.36) by Chaves and Otto (1998). The size structure of different populations and greater feeding availability in bays may cause such differences in allometric coefficients.

The dependence on Sepetiba bay as a rearing ground for D. rhombeus populations has been recorded in this present study, with this species undertaking movements from the outer bay zone towards the adjacent coastal shelf. Diapterus rhombeus is abundant and frequent in Sepetiba bay $\left(23^{\circ} \mathrm{S}\right)$, a coastal area near to its southern limit of distribution $\left(28^{\circ} \mathrm{C}\right)$ on the Santa Catarina coast. Stoner (1986) reported that members of the Gerreidae family are replaced by members of the Sciaenidae family in higher latitudes, declaring the Joyuda Lagoon $\left(18^{\circ} \mathrm{N}\right)$, Porto Rico, where $D$. rhombeus ranked among the most abundant species, to be its northern limit of distribution. Sepetiba bay could be the corresponding southern limit to Joyuda Lagoon in the Southwestern Atlantic Ocean. The positive distribution-abundance relationship posited by Hanski et al. (1993), by which species of wide geographical distribution tend to be more abundant locally than species with more restricted distribution, has been confirmed by this present study. Species able to exploit a wide range of resources become both widespread and locally abundant (Gaston; Lawton, 1990) or there are no interspecific differences in the degree of ecological specialization, but the resources used by some species are both more widespread and locally more abundant than are those used by some other species, yielding the positive distribution-abundance relationship. Size segregation plus an effective adaptation to the environmental conditions of Sepetiba bay seem to be the strategy developed by $D$. rhombeus to attain high abundance and wide distribution.

\section{ACKNOWLEDGEMENTS}

We thank biologists Pablo Mendonça, Roberto Guião, Francisco José da Costa Guimarães, Márcia Cristina Costa de Azevedo, André Luiz Machado Pessanha and Márcio de Araújo Silva for helping in field work. This work was partially supported by $\mathrm{CNPq}$ - Brazilian National Agency for
Scientific and Technological Development (Proc. 474813-03-7).

\section{REFERENCES}

Aguirre-León, A.; Yánez-Arancibia, A.; Amescua-Linares, F. Taxonomía, diversidad, distribución y abundancia de las mojarras de la Laguna de Términos, campeche (Pises:Gerreidae). An. Inst. Cien. Mar y Limn., Univesidad Autónoma del México, México, v. 13, p.369444, 1982.

Araújo, F. G.; Cruz-Filho, A. G.; Azevedo, M. C. C.; Santos, A. C. A. Estrutura da comunidade de peixes demersais da Baía de Sepetiba. Rev. Bras. Biol., Rio de Janeiro, v. 58, p.417-430, 1998.

Araújo, F. G.; Santos, A. C. A. Distribution and recruitment of mojarras (Perciformes, Gerreidae) in the continental margin of Sepetiba Bay, Brazil. Bull. Mar. Sci.,v. 65, p.431-439, 1999.

Araújo, F. G.; Gomes, I. D.; Bertoldo, I. C. Proporção sexual e período reprodutivo de três espécies de Gerreidae (Osteichthyes, Perciformes) na Baía de Sepetiba, RJ. Rev. Bras. Med. Vet., v. 21, p.207-210, 1999.

Araújo, F. G.; Azevedo, M. C. C.; Silva, M. A.; Pessanha, A. L. M.; Gomes, I. D.; Cruz-Filho, A. G. Environmental influences on the demersal fish assemblages in the Sepetiba Bay, Brazil. Estuar., v. 15, p.441-450, 2002.

Austin, H. M. Some aspects of the rhomboid mojarra Diapterus rhombeus in Puerto Rico. Bull. Mar. Sci., 21: 886-903, 1971.

Ayala-Perez, L. A.; Gomes-Montes, A. B.; Ramos Miranda, J. Distribución, abundancia y parámetros poblacionales de la mojarra Diapterus rhombeus (Pisces:Gerreidae) en la Laguna de Términos, Campeche, México. Rev. Biol. Trop., v. 49, p. 635-642, 2001.

Barroso, L. V. Diagnóstico ambiental para a pesca de águas interiores no estado do Rio de Janeiro. MINTER/IBAMA-RJ/ACUMEP, Rio de Janeiro: 1989, 177p.

Blaber, S. J. M.; Blaber, T. G. Factores affecting the distribution of juvenile estuarine and inshore fish. J. Fish Biol., v. 17, p.143-162, 1980.

Blaber, S. J. M.; Brewer, D. T.; Salini, J. P. Fish communities and the nursery role of a tropical bay in the Gulf of Carpentaria, Australia. Estuar., Coast. Shelf Sci., v. 40, p.177-193, 1985.

Cervigón, F.; Gómez. A. Las lagunas litorales de la Isla Margarita. Cent. Investig. Cient., Univ. Orient., Núc. Nuev. Espart., Venezuela. 1986, 89p.

Chaves, P. T. C.; Otto G. Aspectos biológicos de Diapterus rhombeus (Cuvier) (Teleostei, Gerreidae) na Baía de Guaratuba, Paraná, Brasil. Rev. Bras. Zool. v. 15, p. 289-295, 1998.

Coelho, V. M. B.; Carvalho, R. R. Levantamento Sanitário da Baía de Sepetiba e suas possibilidades como corpo receptor de cargas poluidoras da Região. Rio de Janeiro. Pub. Avul. FEEMA, 1973, 87p.

Cyrus, D. P.; Blaber, S. J. M. The reproductive biology of Gerres in Natal estuaries. J. Fish Biol., v. 24, p.491-504, 1984.

Etchevers, S. L. Contribution to the biology of Diapterus rhombeus (Cuvier) (Pisces-Gerreidae), south of Margarita island, Venezuela. Bull. Mar. Sci., v. 28, p.385-389, 1978. 
Gaston, K. J.; Lawton, J. H. Effects of scale and habitat on the relationship between regional distribution and local abundance. Oikos, v. 58, p.329-335, 1990.

Gayanilo Jr., F. C.; Pauly, D. FAO-ICLARM Stock Assessment Tools (FISAT). Reference manual. FAO comput. Info. Ser. (Fisheries) 8, 1997, 249 p.

GIBSON, R. N.; PIHL, L.; BURROWS, M. T.; MODIN, J.; WENNHAGE, H.; NICKELL, L.A. Diel moviments of juvenile plaice Pleuronectes platessa in relation to predators, competitors, food availability and abiotic factors on a microtidal nursery ground. Mar. Ecol. Progr. Ser., v. 165, p.145-159, 1998

GRIFFITHS, S. P. Factors influencing fish composition in an Australian intermittently open estuary. Is stability salinity-dependent? Estuar., Coast. Shelf Sci., v. 52, p.739-751, 2001.

HANSKI, I.; KOUKI, J.; HALKKA, A. Three explanations of the positive relationship between distribution and abundance of species. In Species diversity in ecological communities - historical and geographical perspectives, p.108-116. Edited by RICKLEFS, R.E.; SCHLUTER, D. The University Chicago Press, Chicago, 1993, 416 p.

LE CREN, E. D. M. The length-weight relationship and seasonal cycle in gonad weight and conditions in the perch Perca fluviatilis. J. Anim. Ecol., v. 20, p.201-1, 1951.

LIVINGSTON, R. J.; KOBYLINSKI, G. J.; LEWIS, F. G.; SHERIDON, P. F. Long-term flutuactions of epibenthic fish and invertebrate populations in Apalachiola Bay, Florida. Fish. Bull., v. 74, p.311-321, 1976.

MARTINO, E. J.; ABLE, K.W. Fish assemblages across the marine to low salinity transition zone of a temperate estuary. Estuar., Coast. Shelf Sci., v. 56, p.969-987, 2003.

MUTO, E. Y.; SOARES, L. S. H.; ROSSIWONGSTSCHOWSKI, C. L. D. B. Length-weight relationship of marine fish species off São Sebastião system, São Paulo, southeastern Brazil. Naga, the ICLARM Quart., v. 23, p.27-29, 2000.

PETERSON, A. W.; WHITFIELD, A. K. Do shallow water habitats function as refugee for juvenile fishes? Estuar., Coast. Shelf Sci., v. 51, p.359-364, 2000.

PFEIFFER, W. C.; LACERDA, L. D.; FISZMAN, M.; LIMA, R. W. Heavy metal in fishes from Sepetiba Bay, Rio de Janeiro State. Ciênc. Cult., v. 37, p.297-302, 1985.

RICKLEFS, R. E. Economia da Natureza. Rio de Janeiro, Guanabara Koogan, 2003, 469p.

SANTOS, E. P. Dinâmica de populações aplicada à pesca e à piscicultura. São Paulo, Hucitec, Universidade de São Paulo, 1978, 129p.
SANTOS, A. C. A.; ARAÚJO, F. G. Hábitos alimentares de três espécies de Gerreidae (Osteichthyes, Perciformes) na Baía de Sepetiba, RJ. Arq. Biol. Tec., v. 40, p.359-368, 1997.

SANTOS, A. C. A.; ARAÚJO, F. G.; CRUZ-FILHO, A. G.; AZEVEDO, M. C. C. Distribuição e abundância relativa de Gerreidae (Osteichthyes, Perciformes) na Baía de Sepetiba, RJ. Arq. Biol. Tec., v. 40, p.672-686, 1997.

SIGNORINI, S. R. A study of the circulation in bay of Ilha Grande and bay of Sepetiba, part I, a survey of the circulation based on experimental field data. Bol. Inst. Oceanogr., São Paulo v. 29, p.41-55, 1980.

STONER, A. W. Community structure of the demersal fish species of Laguna Joyuda, Puerto Rico. Estuar., v. 9, p.142-152, 1986.

TAYLOR, C. C. Growth equations with metabolic parameters. J. Counc.Internat. Explorat. Sea, Copenhagen, v. 27, p. 270-286, 1962.

TEIXEIRA, R. L.; HELMER, J. L. Ecology of young mojarras (Pisces:Gerreidae) occupying the shallow waters of a tropical estuary. Rev. Bras. Biol., v. 57, p.637-646, 1997.

THAYER, G. W.; COLBY, Y. D. R.; HETTLER JR., W. F. Utilization of the red mangrove prop root habitat by fishes in South Florida. Mar. Ecol. Progr. Ser., v. 35, p.25-38, 1987.

THIEL, R.; POTTER, I. C. The ichthyofauna of the Elbe Estuary: an analysis in space and time. Mar. Biol., v. 138, p.603-616, 2001.

VAZZOLER, A. E. A. M. Biologia da reprodução de peixes teleósteos: teoria e prática. Maringá, $P R$, Eduem, 1996, 169p.

WAGNER, M. C.; AUSTIN, H. M. Correspondence between environmental gradients and summer littoral fish assemblages in low salinity reaches of the Chesapeake Bay, USA. Mar. Ecol. Progr. Ser., v. 177, p.197-212, 1999.

WEINSTEIN, M. P.; WEISS, S. L.; WALTERS, M. F. Multiple determinants of community structure in shallow marsh habitats, Cape Fear River Estuary, North Carolina, USA. Mar. Biol., v. 58, p.227-243, 1980.

ZAR, J. H. Biostatistical Analysis. 3rd edition. Prentice Hall, Englewoods Cliffs, 1996, 662 p.

YÁÑEZ-ARANCIBIA, A.; SANCHEZ-GIL, P. Ecologia de los recursos demersales marinos, Fundamentos en costas tropicales. AGT Editor, México, 1988, 228p.

(Manuscript received 26 July 2011; revised 17 October 2011; accepted 05 March 2012) 